\title{
Cowpea bean production under water stress using hydrogels ${ }^{1}$
}

\author{
Marília Barcelos Souza Lopes ${ }^{2}$, Taynar Coelho de Oliveira Tavares², \\ Danilo Alves Veloso ${ }^{2}$, Niléia Cristina da Silva ${ }^{2}$, Rodrigo Ribeiro Fidelis ${ }^{2}$
}

\section{ABSTRACT}

The population increase and the need of intensifying food production, coupled with the scarcity of water resources, have led to the search of alternatives that reduce consumption and optimize the water use during cultivation. In this context, hydrogels become a strategy in agricultural management, due to their water retention capacity in the soil and availability to plants. This study aimed at evaluating the efficiency of hydrogels on the development and production of cowpea bean ('Sempre-verde' cultivar) under water stress, in a greenhouse. The experiment was performed in a randomized block design, with five replications, in a $4 \times 5$ factorial scheme, consisting of four types of hydrogel (Hydroplan-EB HyA, with granulometry of 1-3 mm; Hydroplan-EB HyB, with granulometry of $0.5-1 \mathrm{~mm}$; Hydroplan-EB HyC, with granulometry $<0.5 \mathrm{~mm}$; Polim-Agri, with granulometry of $1-0.5 \mathrm{~mm})$ and five concentrations $\left(0 \mathrm{~g} \mathrm{pot}^{-1} ; 1.5 \mathrm{~g} \mathrm{pot}^{-1}\right.$; $\left.3 \mathrm{~g} \mathrm{pot}^{-1} ; 4.5 \mathrm{~g} \mathrm{pot}^{-1} ; 6 \mathrm{~g} \mathrm{pot}^{-1}\right)$. The following traits were evaluated: number of pods per plant, number of grains per pod and grain yield. The highest concentration $\left(6 \mathrm{~g} \mathrm{pot}^{-1}\right)$ resulted in a higher number of pods and yield for all the hydrogels, especially for $\mathrm{HyC}$ and Polim-Agro, which presented 7.4 pods plant $^{-1}$ and 7.0 pods plant $^{-1}$, with yield of 15.43 g plant $^{-1}$ and $16.68 \mathrm{~g} \mathrm{plant}^{-1}$, respectively. The use of hydrogel shows to be efficient for reducing yield losses under water stress.

KEYWORDS: Vigna Unguiculata (L.) Walp.; soil conditioner; drought.

\section{INTRODUCTION}

According to the Food and Agriculture Organization of the United Nations estimations (FAO 2016), food production needs to increase more than $70 \%$, in order to attend the increasing demand (Cargnin 2007), since the world population is estimated to reach 9.1 billion people up to 2050 . Therefore, new management strategies have been researched to stimulate the food production increase,

\section{RESUMO}

Produção de feijão-caupi sob estresse hídrico utilizando-se hidrogéis

O aumento populacional e a necessidade de intensificação da produção de alimentos, aliados à escassez de recursos hídricos, têm levado a buscas por alternativas que reduzam o consumo e otimizem o uso de água durante os cultivos. Neste contexto, os hidrogéis surgem como estratégia no manejo agrícola, devido à sua capacidade de retenção e de disponibilização de água para as plantas. Objetivou-se avaliar a eficiência de hidrogéis no desenvolvimento e produção de feijão-caupi (cultivar 'Sempre-verde'), quando submetido a estresse hídrico, em casa-de-vegetação. O experimento foi conduzido em blocos casualizados, com cinco repetições, em esquema fatorial $4 \times 5$, sendo avaliados quatro tipos de hidrogel (Hydroplan-EB HyA, com granulometria de 1-3 mm; Hydroplan-EB HyB, com granulometria de 0,5-1 mm; Hydroplan-EB HyC, com granulometria $<0,5 \mathrm{~mm}$; Polim-Agri, com granulometria de 1-0,5 mm) e cinco concentrações (0 g vaso $\left.{ }^{-1} ; 1,5 \mathrm{~g} \mathrm{vaso}^{-1} ; 3 \mathrm{~g} \mathrm{vaso}^{-1} ; 4,5 \mathrm{~g} \mathrm{vaso}^{-1} ; 6 \mathrm{~g} \mathrm{vaso}^{-1}\right)$. Os parâmetros avaliados foram: número de vagens por planta, número de grãos por vagem e produtividade de grãos. A maior concentração $\left(6 \mathrm{~g} \mathrm{vaso}^{-1}\right)$ resultou em maior número de vagens e produtividade para todos os hidrogéis, destacando-se HyC e Polim-Agro, com 7,4 e 7 vagens por planta e produtividade de 15,43 $\mathrm{g} \mathrm{planta}^{-1}$ e 16,68 g planta $^{-1}$, respectivamente. A utilização de hidrogel demonstra ser eficiente na redução de perdas de produtividade sob estresse hídrico.

PALAVRAS-CHAVES: Vigna Unguiculata (L.) Walp.; condicionador de solos; seca.

since the limited availability of land and natural resources are common.

Brazil is one of the world's largest grain producers. However, water availability has been considered a limiting climatic factor, with the greatest effect on agricultural productivity. The grain yield for the 2015/2016 crop season was estimated at 188.1 million tons, with a reduction of $9.5 \%$, if compared to the $2014 / 2015$ crop season. This reduction was mainly attributed to water stress 
(Conab 2016). In the North and Northeast Brazilian regions, the water deficit is even more severe. During cropping and second cropping, the rainfall is quite irregular, causing a phenomenon known as "Indian summer", which consists of a drought period with intense heat, strong insolation and low relative humidity, which severely compromise crop yield (Cardoso \& Ribeiro 2006). In these regions, it is possible to find the largest areas with cowpea [Vigna unguiculata (L.) Walp.], which is important as an employment and income source, constituting one of the main components for human nutrition (Bezerra et al. 2008).

Cowpea cultivation has been expanding to the Brazilian Savannah (North, Northeast and Middle-West), being incorporated into the productive arrangements as a second crop, after soybean and rice crops. As a second crop, cowpea presents a very competitive production cost, increasing the farmers interest in it. In addition, it has a high quality production, enabling the product to be well accepted by all members of its production chain (Freire Filho et al. 2011).

However, water availability is one of the main environmental factors driving crop yield, since water is an essential component in processes like photosynthesis, transpiration and maintenance of carbon dioxide permeability in the leaf mesophyll (Taiz \& Zeiger 2013). In many regions of the world, the water used in agriculture represents about $70 \%$ of the consumption. There is a huge need to reduce this use by eliminating waste and introducing appropriate technologies, reuse and recycling (Tundisi 2008).

In this context, hydro-retentive polymers are an alternative, acting as regulators of water availability for crops, increasing local yield and minimizing production costs (Mendonça et al. 2013). Hydrogels are defined as super-absorbent polymers, consisting of one or more three-dimensionally structured plots formed by macromolecular chains interconnected by covalent bonds (crosslinks) or physical interactions. They can retain a significant amount of water within their own structure and swell without dissolution (Rui et al. 2007, Aouada et al. 2008, Oviedo et al. 2008). The amount of water adsorbed by hydrogels is generally related to the hydrophilicity of the chains and density of the crosslinking agent used in the synthesis (Krusic et al. 2011).

The polymers performance has contributed to increase the water retention capacity, improve soil properties and reduce nutrient leaching, allowing more effective use of soil and water resources, contributing to improve crop development and yield, reducing germination time, decreasing plant death and improving the root system development (Marques \& Bastos 2010). Hydrogels act as reservoirs storing water and dissolved water (such as pesticides and fertilizers) near roots, making this solution readily available to plants, as they need it. According to Azevedo et al. (2002), hydroretentive polymers are an alternative for situations where there is no water availability in the soil, in water stress conditions or when long periods of drought are expected, and when low soil moisture adversely affects the growth and development of plants.

This study aimed at evaluating the efficiency of hydrogel on the cowpea bean production under water stress.

\section{MATERIAL AND METHODS}

The experiment was installed in a greenhouse at the Universidade Federal do Tocantins, in Gurupi,

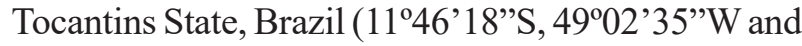
$280 \mathrm{~m}$ of altitude), on March 14 (2015), using the 'Sempre-verde' cowpea bean cultivar. According to Köppen, the climate of the region is metamorphic, with summer rains and dry winter, maximum and minimum temperatures of $30-35^{\circ} \mathrm{C}$ and $20-25^{\circ} \mathrm{C}$, respectively, and relative humidity of approximately $85 \%$ (Brasil 2014).

The greenhouse has an arched roof and is $20 \mathrm{~m}$ long and $6 \mathrm{~m}$ wide, with wall footprint of $1.75 \mathrm{~m}$. The side and front walls consist of $50 \%$ shade cloth, the ceiling is covered with polyethylene plastic film of 150 microns, without climate control, and the pots were positioned on the floor. The soil used in the experiment was a Dystrophic Yellow Red Latosol (0-0.20 m layer), with $\mathrm{pH}$ corrected to 5.5. Pots with capacity of $5 \mathrm{~kg}$ were used, with a mixture of soil, substrate and sand in a 3:1:1 ratio, respectively, with the aim of providing a greater soil porosity and better root development for the crop.

The soil chemical and physical parameters, prior to the beginning of the experiment, were as it follows: $\mathrm{CaCl}_{2} \mathrm{pH}=6.0 ; \mathrm{OM}(\%)=1.5$; $\mathrm{P}(\mathrm{Mel})=9.2 \mathrm{mg} \mathrm{dm}^{-3} ; \mathrm{K}=0.40 \mathrm{cmol}_{\mathrm{c}} \mathrm{dm}^{-3}$; $\mathrm{Ca}+\mathrm{Mg}=2.8 \mathrm{cmol}_{\mathrm{c}} \mathrm{dm}^{-3} ; \mathrm{H}+\mathrm{Al}=1.6 \mathrm{cmol} \mathrm{dm}^{-3}$; $\mathrm{Al}=0.0 \mathrm{cmol}_{\mathrm{c}} \mathrm{dm}^{-3} ; \mathrm{SB}=3.2 \mathrm{cmol}_{\mathrm{c}} \mathrm{dm}^{-3} ; \mathrm{V}=67 \%$; $665 \mathrm{~g} \mathrm{~kg}^{-1}$ of sand; and $50 \mathrm{~g} \mathrm{~kg}^{-1}$ of silt. Fertilization 
was performed at 30 days after sowing, according to the soil analysis, using $400 \mathrm{~kg} \mathrm{ha}^{-1}$ of NPK (5-25-15) and $50 \mathrm{~kg} \mathrm{ha}^{-1}$ of urea.

The seeds were treated with fungicide from the Benzimidazole chemical group $(63+9 \mathrm{~g}$ a.i. $/ 100 \mathrm{~kg}$ of seeds) and the insecticide/fungicide from the Piraclostrobin, Methyl Thiophanate and Fipronil chemical group (100 $\mathrm{g}$ a.i./100 $\mathrm{kg}$ of seeds), following recommendations for the crop.

The experiment was performed in a randomized block design, with five replications, in a 4 x 5 factorial scheme, with four hydrogels. The three commercial polymers Hydroplan - EB ${ }^{\circledR}$ corresponded to a mixed product of cross-linked copolymers of acrylamide and potassium acrylate used to absorb and retain large amounts of water and nutrients. Each polymer, in five concentrations $\left(0 \mathrm{~g} \mathrm{pot}^{-1}, 1.5 \mathrm{~g} \mathrm{pot}^{-1}, 3 \mathrm{~g} \mathrm{pot}^{-1}, 4.5 \mathrm{~g} \mathrm{pot}^{-1}\right.$ and $\left.6 \mathrm{~g} \mathrm{pot}^{-1}\right)$, had the following characteristics: H1 (HyA) - white insoluble appearance granule in water, with particles varying $0.5-3 \mathrm{~mm}$ and absorption capacity between 150 and 200 times its mass in water and 100 times its volume; H2 (HyB) - appearance of a white powder, insoluble in water, with particles $<1 \mathrm{~mm}$ and absorption capacity between 200 and 400 times its mass in water and 100 times its volume; $\mathrm{H} 3$ (HyC) - appearance of a fine white powder, insoluble in water, with particles $<0.5 \mathrm{~mm}$ and absorption capacity of up to 370 times its mass in water and 100 times its volume; H4 (Polim-Agri) belongs to the POLIM-AGRI PP company, derivate from acrylamide/potassium acrylate copolymer, with a granular solid characteristic, insoluble in water, with particles ranging 1-0.5 mm. A standard treatment (no water stress throughout the crop cycle) was added to the experiment, with the aim of comparing how the influence of the products studied in a stress environment approach the ideal environment. However, it was not submitted to the statistical analysis and is presented in bar graphs.

The hydrogel was applied as powder, with about $8 \mathrm{~cm}$ of depth, in a circle. Right above, about $5 \mathrm{~cm}$, the sowing was also performed in a circle. Five seeds per pot were sown, with thinning at 25 days after sowing, to maintain three plants per pot. The pot capacity was adopted as the water content in the soil after being saturated through the action of gravity until the end of drainage. The irrigation of pots was controlled through the weighing procedure, where pots were weighed daily for later replacement of the evapotranspirated water in the period, keeping the humidity near to the field capacity and never with a pressure higher than $30 \mathrm{kPa}$, which is considered as ideal for the crop. Assuming that the tap water presented a weight/volume ratio of $1: 1$, irrigation was performed in order to complete the missing water, in terms of volume $(\mathrm{mL})$, using a methodology adapted from Moraes et al. (2008). In the flowering period (45 days after sowing), irrigation was interrupted for 20 days, when the highest tension was measured with the aid of a tensiometer of $75 \mathrm{kPa}$.

Phytosanitary treatments were performed according to the necessity of insecticide applications: Mospilan at $250 \mathrm{~g} \mathrm{ha}^{-1}$, Nativo at $180 \mathrm{~g} \mathrm{ha}^{-1}$ and oxime methylcarbamate $(107 \mathrm{~g}$ of a.i./100 $\mathrm{mL}$ of water). The evaluations were performed at 68 days after sowing. The number of pods per plant was evaluated by counting the total number of pods in the pot and divided by the number of pots (three) (NPP = $\mathrm{TP} / 3$ ). The number of grains per pod was obtained through the total number of grains originated from the plants of each pot and divided by the result of the total number of pods of the three plants (NGP = TG/NPP). The grain yield was obtained by the grain mass of the plants in the pot divided by the amount of pot plants (three) $($ YIELD $=\mathrm{GM} / 3)$, in g plant $^{-1}$, corrected to $13 \%$ of moisture.

The experimental data were submitted to analysis of variance, with application of the $\mathrm{F}$ test at $1 \%$ and $5 \%$. The regression analysis was performed using the Sisvar software.

\section{RESULTS AND DISCUSSION}

According to the analysis of variance (Table 1), it is possible to observe a significant effect of the interaction for all variables evaluated, evidencing

Table 1. Analysis of variance for number of pods per plant (NPP), number of grains per pod (NGP) and yield $\left(\mathrm{g}\right.$ plant $\left.{ }^{-1}\right)$ for one cowpea cultivar with five concentrations and four hydrogel sources.

\begin{tabular}{lrccc}
\hline \multicolumn{1}{c}{ Source } & D.F. & NPP & NGP & Yield \\
\hline Repetition & 4 & 1.63 & 1.15 & 0.38 \\
Hydrogel $(\mathrm{H})$ & 3 & $7.45^{*} *$ & $9.39 * *$ & $11.96 * *$ \\
Concentration $(\mathrm{C})$ & 4 & $58.23 * *$ & $5.21 * *$ & $452.64 * *$ \\
H x C & 12 & $0.94 * *$ & $2.78 * *$ & $1.18^{* *}$ \\
Residue & 76 & 0.72 & 0.85 & 0.22 \\
\hline CV $(\%)$ & \multicolumn{5}{c}{20.29} & 21.39 & 7.89 \\
\hline Mean & 4.21 & 4.32 & 5.97 \\
** Significant for $\mathrm{p} \leq 0.01$, &
\end{tabular}

** Significant for $\mathrm{p} \leq 0.01$, according to the $\mathrm{F}$ test. 
that factors are dependent. Significant differences were observed for all characteristics, i.e., number of pods per plant, number of grains per pod and grain yield, after the application of increasing hydrogel concentrations and different commercial products.

Table 2 shows the mean values of the polymers for the five concentrations evaluated. The polymer H4 (Polim-Agri) stands out for presenting higher averages for all characteristics evaluated at all doses, although it was similar to the polymer $\mathrm{H} 3$ ( $\mathrm{HyC}$ ), for the characteristic number of pods per plant and grain yield in $\mathrm{C} 2, \mathrm{C} 3$ and $\mathrm{C} 4$.

Regarding the number of pods per plant, the hydrogel types presented a different behavior (Figure 1), especially HyC and Polim-Agri, which have a lower granulometry $(<0.5 \mathrm{~mm}$ and $0.5 \mathrm{~mm}$, respectively) and were the only ones to always compose the statistical group of higher averages. These hydrogels produced 7.4 and 7 pods at the highest concentration, respectively, whereas the control produced 9.2 pods per plant. This result may be associated with several factors, such as a smaller particle size, and enhanced a specific surface area and, consequently, a higher water absorption of these hydrogels. The structure determines the water retention, where the larger the particle size, the smaller the water retention force.

Brito et al. (2013) explain that the swelling process of a hydrogel is controlled by physical

Table 2. Average number of pods per plant, number of grains per pod and grain yield for each hydrogel and its concentration.

\begin{tabular}{|c|c|c|c|c|c|}
\hline \multicolumn{6}{|c|}{ Number of pods per plant } \\
\hline Hydrogel & $0 \mathrm{~g} \mathrm{pot}^{-1}$ & $1.5 \mathrm{~g} \mathrm{pot}^{-1}$ & $3 \mathrm{~g} \mathrm{pot}^{-1}$ & $4.5 \mathrm{~g} \mathrm{pot}^{-1}$ & $6 \mathrm{~g} \mathrm{pot}^{-1}$ \\
\hline H1 & $2.40 \mathrm{~A}^{*}$ & $2.60 \mathrm{AB}$ & $3.40 \mathrm{BC}$ & $4.40 \mathrm{AB}$ & $6.20 \mathrm{~B}$ \\
\hline $\mathrm{H} 2$ & $2.40 \mathrm{~A}$ & $2.40 \mathrm{~B}$ & $3.00 \mathrm{C}$ & $4.00 \mathrm{~B}$ & $6.60 \mathrm{~B}$ \\
\hline H3 & $2.40 \mathrm{~A}$ & $3.80 \mathrm{~A}$ & $4.60 \mathrm{AB}$ & $5.00 \mathrm{AB}$ & $7.40 \mathrm{~A}$ \\
\hline $\mathrm{H} 4$ & $2.40 \mathrm{~A}$ & $3.60 \mathrm{~A}$ & $5.20 \mathrm{~A}$ & $5.60 \mathrm{~A}$ & $7.00 \mathrm{~A}$ \\
\hline \multicolumn{6}{|c|}{ Number of grains per pod } \\
\hline Hydrogel & $0 \mathrm{~g} \mathrm{pot}^{-1}$ & $1.5 \mathrm{~g} \mathrm{pot}^{-1}$ & $3 \mathrm{~g} \mathrm{pot}^{-1}$ & $4.5 \mathrm{~g} \mathrm{pot}^{-1}$ & $6 \mathrm{~g} \mathrm{pot}^{-1}$ \\
\hline $\mathrm{H} 1$ & $3.58 \mathrm{~A}$ & $5.12 \mathrm{AB}$ & $4.02 \mathrm{~A}$ & $3.50 \mathrm{~B}$ & $4.04 \mathrm{~B}$ \\
\hline $\mathrm{H} 2$ & $3.58 \mathrm{~A}$ & $5.38 \mathrm{~A}$ & $4.50 \mathrm{~A}$ & $3.74 \mathrm{~B}$ & $3.98 \mathrm{~B}$ \\
\hline H3 & $3.58 \mathrm{~A}$ & $3.80 \mathrm{~B}$ & $3.30 \mathrm{~A}$ & $3.72 \mathrm{~B}$ & $4.62 \mathrm{~B}$ \\
\hline $\mathrm{H} 4$ & $3.58 \mathrm{~A}$ & $4.78 \mathrm{~A}$ & $4.82 \mathrm{~A}$ & $6.14 \mathrm{~A}$ & $6.70 \mathrm{~A}$ \\
\hline
\end{tabular}

Hydrogel $0 \mathrm{~g} \mathrm{pot}^{-1} 1.5 \mathrm{~g} \mathrm{pot}^{-1} \quad 3 \mathrm{~g} \mathrm{pot}^{-1} 4.5 \mathrm{~g} \mathrm{pot}^{-1} \quad 6 \mathrm{~g} \mathrm{pot}^{-1}$

\begin{tabular}{llllll}
$\mathrm{H} 1$ & $2.56 \mathrm{~A}$ & $2.86 \mathrm{C}$ & $3.40 \mathrm{C}$ & $4.32 \mathrm{~B}$ & $12.71 \mathrm{C}$ \\
$\mathrm{H} 2$ & $2.56 \mathrm{~A}$ & $3.19 \mathrm{BC}$ & $3.81 \mathrm{BC}$ & $4.45 \mathrm{~B}$ & $14.44 \mathrm{~B}$ \\
$\mathrm{H} 3$ & $2.56 \mathrm{~A}$ & $3.68 \mathrm{~B}$ & $4.56 \mathrm{AB}$ & $5.79 \mathrm{~A}$ & $14.75 \mathrm{~A}$ \\
$\mathrm{H} 4$ & $2.56 \mathrm{~A}$ & $4.65 \mathrm{~A}$ & $5.30 \mathrm{~A}$ & $5.99 \mathrm{~A}$ & $15.44 \mathrm{~A}$ \\
\hline
\end{tabular}

* Means followed by the same letter in the column belong to the same statistical group by the Tukey test at $5 \%$. H1: HyA; H2: HyB; H3: HyC; H4: Polim-Agri. factors intrinsic to the 3D network, as well as external factors. Some physical factors, such as the presence of hydrophilic groups $\left(-\mathrm{OH},-\mathrm{NH}_{2},-\mathrm{COOH}\right.$, $\left.-\mathrm{CONH}_{2},-\mathrm{SO}_{3} \mathrm{H}\right)$ in the polymer chain structure (laterally or in the main chain), lower crosslink density and high flexibility of the polymer network, can contribute positively to a greater swelling of the material. Bortolin et al. (2012) explain that higher concentrations of acrylamide increase the stiffness of the polymer chains, resulting in less water absorption capacity. Generally, polymer networks formed with high AAm concentration are more strongly crosslinked and this reflects in less expansion, causing lower volume of water diffused into the matrix. Thus, the hydrogels HyC and Polim-Agri probably have a characteristic that results in a greater absorption of water and, consequently, a greater availability of water to the plant along its cycle, resulting in a greater number of pods per plant.

Observing the variable number of grains per pod (Figure 2), it is possible to notice a cubic response for this characteristic, regarding all hydrogels evaluated. This response can be related to the stable varietal character, not influenced by the environment. Scherer et al. (2015) tested times and concentrations of nitrogen fertilization for the bean crop and did not obtain a positive response for the number of grains per pod, as a function of the fertilization increment. The authors explain that this is a variable of qualitative characteristic,

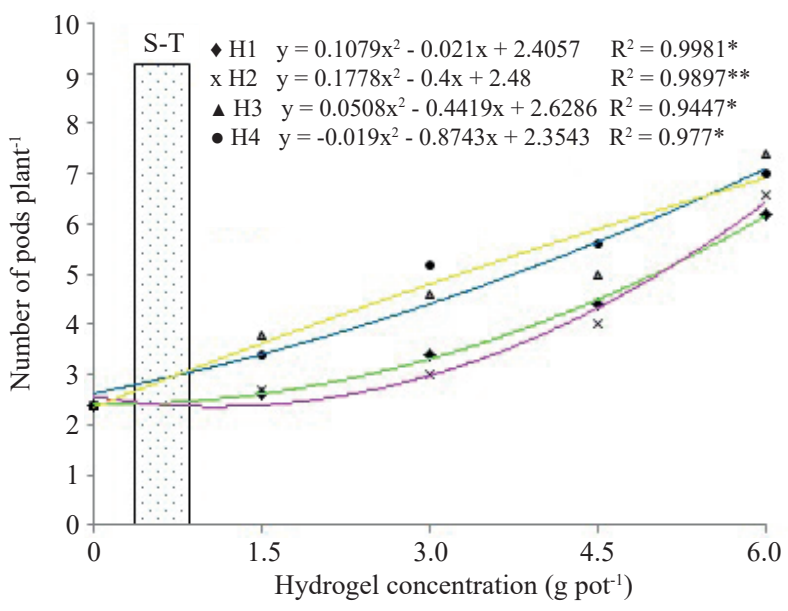

Figure 1. Number of pods per plant of cowpea bean cv. 'Sempreverde' submitted to different concentrations $\left(0 \mathrm{~g} \mathrm{pot}^{-1}\right.$, $1.5 \mathrm{~g} \mathrm{pot}^{-1}, 3 \mathrm{~g} \mathrm{pot}^{-1}, 4.5 \mathrm{~g} \mathrm{pot}^{-1}$ and $\left.6 \mathrm{~g} \mathrm{pot}^{-1}\right)$ and commercial products (H1: HyA; H2: HyB; H3: HyC; H4: Polim-Agri). S-T: standard treatment, with no water stress; ${ }^{n s}$ not significant; $* *$ significant for $\mathrm{p} \leq 0.01$; $*$ significant for $\mathrm{p} \leq 0.05$, according to the $\mathrm{F}$ test. 
being little influenced by the environment. The highest production (6.7 grains) was observed at the maximum concentration for the Polim-Agri hydrogel, which is $7.61 \%$ higher than the control.

Therefore, even when submitted to 20-day water stress in the most critical period of the crop (flowering), the formation of beans in the pod was higher than for the control, highlighting the potential of the product to supply the plants nutritional and water needs during this period of adversity, which is common in the region studied. Navroski et al. (2015) concluded that the use of hydrogel increases the water retention capacity in the soil and the content of macronutrients in shoots of Eucalyptus dunnii seedlings.

It is possible to observe an increase in grain yield (Figure 3) for all hydrogels, according to the concentration increase. Polim-Agri presented a yield of $16.68 \mathrm{~g}$ for the highest concentration, higher than that obtained by the control (15.88 g plant $\left.^{-1}\right)$, receiving water during the whole cycle. For the other characteristics, HyC resulted in a yield of $15.43 \mathrm{~g} \mathrm{plant}^{-1}$ for the highest concentration, being $97 \%$ of the control. Nascimento et al. (2011) evaluated 20 cowpea genotypes submitted to water stress and observed yields of 10.6-2.55 g plant $^{-1}$ in the Ceará State, Brazil, explaining that the water stress was the main factor responsible for the low yield.

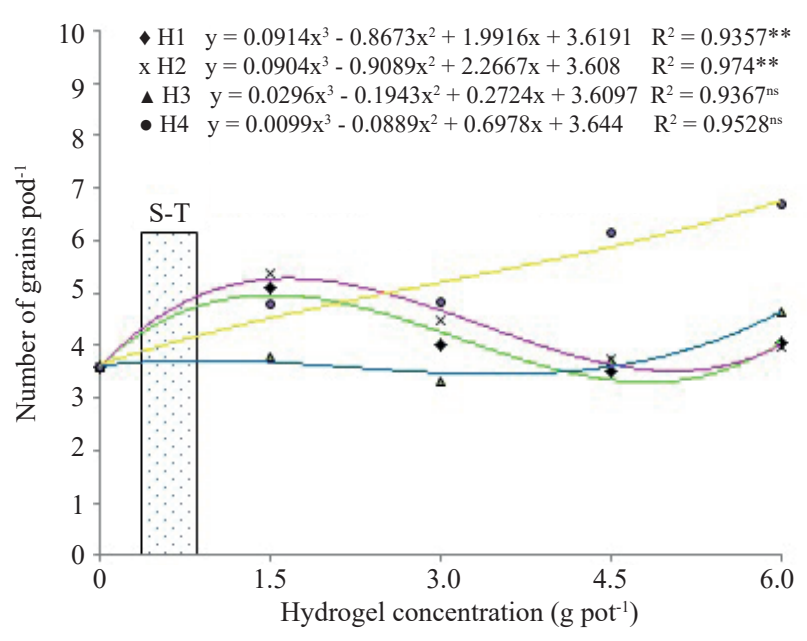

Figure 2. Number of grains per pod of cowpea bean cv. 'Sempreverde' submitted to different concentrations $\left(0 \mathrm{~g} \mathrm{pot}^{-1}\right.$, $1.5 \mathrm{~g} \mathrm{pot}^{-1}, 3 \mathrm{~g} \mathrm{pot}^{-1}, 4.5 \mathrm{~g} \mathrm{pot}^{-1}$ and $\left.6 \mathrm{~g} \mathrm{pot}^{-1}\right)$ and commercial products (H1: HyA; $\mathrm{H} 2$ : $\mathrm{HyB}$; $\mathrm{H} 3$ : $\mathrm{HyC}$; H4: Polim-Agri). S-T: standard treatment, with no water stress; ${ }^{n s}$ not significant; $* *$ significant for $\mathrm{p} \leq 0.01$; $*$ significant for $\mathrm{p} \leq 0.05$, according to the $\mathrm{F}$ test.
Considering the adverse conditions to which the plants were submitted, such as low pot space, limited light, high temperature and water deficit, the yield of the evaluated plants, at the maximum concentration of $\mathrm{HyC}$ and PolimAgri, may be considered satisfactory. Silva et al. (2013), analyzing cultivars of irrigated beans for the production of green grains, in Serra Talhada, Pernambuco State, Brazil, observed a grain yield for the 'Sempre-verde' cultivar (same as this present study) of $13.18 \mathrm{~g} \mathrm{plant}^{-1}$, with spacing of $0.50 \mathrm{~m}$ between rows. According to Dranski et al. (2013), the use of this polymer mixed to the soil supports the hypothesis of water storage and availability under the experimental conditions studied. The water retention polymer has been commercialized with the justifications that, when incorporated into the soil or substrate, it allows a higher water and fertilizer retention, which can be slowly released to the plants in function of the absorption-release cycles. The addition of hydrogel, due to its high cation exchange capacity, reduces nutrient leaching. Thus, it is noticed that the use of hydrogel in agriculture becomes promising, since it guarantees the grower production, availability of water and nutrients, even when the crop is exposed to water stress in critical periods (flowering), since it guarantees the grower the crop safety, raising yield.

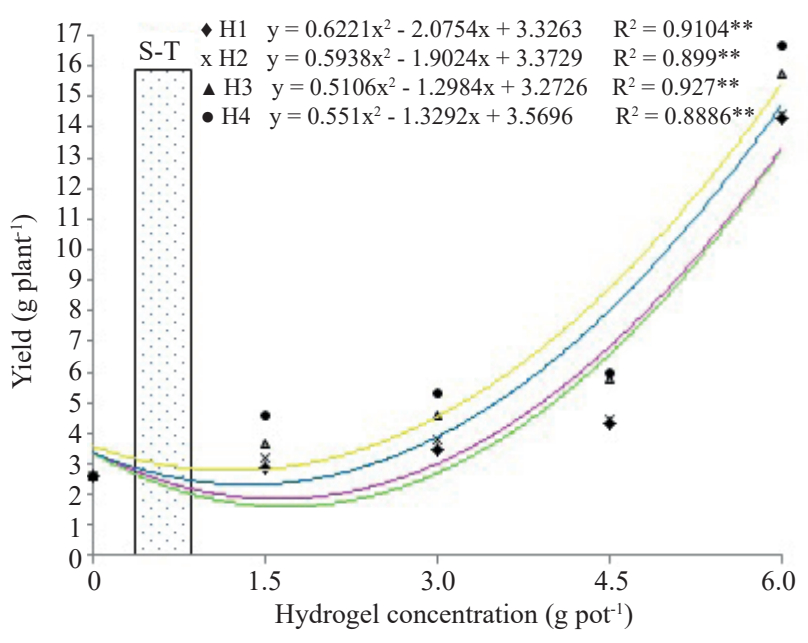

Figure 3. Grain yield of cowpea bean cv. 'Sempre-verde' submitted to different concentrations $\left(0 \mathrm{~g} \mathrm{pot}^{-1}, 1.5 \mathrm{~g} \mathrm{pot}^{-1}, 3 \mathrm{~g} \mathrm{pot}^{-1}\right.$, $4.5 \mathrm{~g} \mathrm{pot}^{-1}$ and $\left.6 \mathrm{~g} \mathrm{pot}^{-1}\right)$ and commercial products (H1: HyA; H2: HyB; H3: HyC; H4: Polim-Agri). S-T: standard treatment, with no water stress; ${ }^{\text {ns }}$ not significant; $* *$ significant for $\mathrm{p} \leq 0.01 ; *$ significant for $\mathrm{p} \leq 0.05$, according to the $\mathrm{F}$ test. 


\section{CONCLUSIONS}

1. The use of hydrogel is an alternative to reduce yield losses caused by drought;

2. The highest concentration of hydrogel $\left(6 \mathrm{~g} \mathrm{pot}^{-1}\right)$ resulted in a higher yield for all hydrogels tested;

3 . The hydrogel polymer influences drought tolerance and, consequently, the yield of plants under drought stress.

\section{REFERENCES}

AOUADA, F. A. et al. Caracterização de hidrogéis condutores constituídos por PAAm e PEDOT/PSS por meio de planejamento fatorial. Polímeros, v. 18, n. 2, p. 126-131, 2008.

AZEVEDO, T. L. F. et al. Uso do hidrogel na agricultura. Revista do Programa de Ciências Agro-Florestais, v. 1, n. 1, p. 23-31, 2002.

BEZERRA, A. A. C. et al. Morfologia e produção de grãos em linhagens modernas de feijão-caupi submetidas a diferentes densidades populacionais. Revista de Biologia e Ciências da Terra, v. 8, n. 1, p. 85-93, 2008.

BORTOLIN, A. et al. Investigação do processo de absorção de água de hidrogéis de polissacarídeo: efeito da carga iônica, presença de sais, concentrações de monômeros e polissacarídeo. Polímeros, v. 22, n. 4, p. 311-317, 2012.

BRASIL. Instituto Nacional de Meteorologia. Aspectos climáticos e sinóticos no Brasil. 2014. Available at: $<$ http://www.inmet.gov.br/portal/index.php?r=home/ page\&page $=$ rede_estaçoes_outo_graf $>$. Access on: Aug. 08, 2016.

BRITO, C. W. Q. et al. Síntese e caracterização de hidrogéis compósitos a partir de copolímeros acrilamidaacrilato e caulim: efeito da constituição de diferentes caulins do Nordeste brasileiro. Química Nova, v. 36, n. 1, p. 40-45, 2013.

CARDOSO, M. J.; RIBEIRO, V. Q. Desempenho agronômico do feijão-caupi, cv. Rouxinol, em função de espaçamento entre linhas e densidade de plantas sob regime de sequeiro. Ciência Agronômica, v. 37, n. 1, p. 12-105, 2006.

CARGNIN, A. Melhoramento de plantas: progresso genético e ambiental. Planaltina: Embrapa Cerrados, 2007.

COMPANHIA NACIONAL DE ABASTECIMENTO (Conab). Acompanhamento da safra brasileira de grãos: safra 2015/2016, 11 ${ }^{\circ}$ levantamento. 2016. Available at: <http://www.conab.gov.br/OlalaCMS/ uploads/arquivos/16 $08 \quad 09 \quad 09 \quad 00 \quad 07$ boletim graos agosto_2016_.pdf $>$. Access on: Sep. 23, 2016.
DRANSKI, J. A. L. et al. Sobrevivência e crescimento do pinhão-manso em função do método de aplicação e formulações de hidrogel. Revista Brasileira de Engenharia Agrícola e Ambiental, v. 17, n. 5, p. 537-542, 2013.

FOOD AND AGRICULTURE ORGANIZATION (FAO). Countries by commodity. 2016. Available at: $<$ http:// faostat.fao.org/site/437/default.aspx $>$. Access on: Sep. 20, 2016.

FREIRE FILHO, F. R. et al. Feijão caupi no Brasil: produção, melhoramento genético, avanços e desafios. Teresina: Embrapa Meio-Norte, 2011.

KRUŠIĆ, K. et al. Preparation and characterization of $\mathrm{pH}$-sensitive hydrogels based on chitosan, itaconic acid and methacrylic acid. Polymer International, v. 60, n. 3, p. 443-452, 2011.

MARQUES, P. A. A.; BASTOS, R. O. Uso de diferentes doses de hidrogel para produção de mudas de pimentão. Pesquisa Aplicada \& Agrotecnologia, v. 3, n. 2, p. 53-57, 2010.

MENDONÇA, T. G. et al. Hidrogel como alternativa no aumento da capacidade de armazenamento de água no solo. Water Resources and Irrigation Management, v. 2, n. 2, p. 87-92, 2013.

MORAES, W. B. et al. Avaliação de linhagens promissoras de feijoeiro tolerantes à seca. Revista Brasileira de Ciências Agrárias, v. 3, n. 2, p. 121-125, 2008.

NASCIMENTO, S. P. et al. Tolerância ao déficit hídrico em genótipos de feijão-caupi. Revista Brasileira de Engenharia Agrícola e Ambiental, v. 15, n. 8, p. 853-860, 2011

NAVROSKI, M. C. et al. Influência do hidrogel no crescimento e no teor de nutrientes das mudas de Eucalyptus dunnii. Floresta, v. 45, n. 2, p. 315-328, 2015.

OVIEDO, I. R. et al. Design of a physical and nontoxic crosslinked poly (vinyl alcohol) hydrogel. International Journal of Polymeric Materials and Polymeric Biomaterials, v. 57, n. 12, p. 1095-1103, 2008.

RUI, L. et al. Controlled release NPK compound fertilizer with the function of water retention. Reactive and Functional Polymers, v. 67, n. 9, p. 769-779, 2007.

SCHERER, A. L. et al. Efeito de diferentes épocas e doses de aplicação de nitrogênio na cultura do feijoeiro cultivado em Campo Grande - MS. Revista Cultivando o Saber, v. 8, n. 2, p. 162-171, 2015.

SILVA, E. F. et al. Avaliação de cultivares de feijão-caupi irrigado para produção de grãos verdes em Serra Talhada PE. Revista Caatinga, v. 26, n. 1, p. 21-26, 2013.

TAIZ, L.; ZEIGER, E. (Eds.). Fisiologia vegetal. Porto Alegre: Artmed, 2013.

TUNDISI, J. G. Recursos hídricos no futuro: problemas e soluções. Estudos Avançados, v. 63, n. 22, p. 7-16, 2008. 